\title{
Total Mercury in Yellow Knights (Tricholoma equestre) Mushrooms and Beneath Soils
}

\author{
Dawid Maćkiewicz $\cdot$ Jerzy Falandysz
}

Received: 6 April 2012/ Accepted: 17 July 2012/Published online: 7 August 2012

(c) The Author(s) 2012. This article is published with open access at Springerlink.com

\begin{abstract}
Mercury has been determined in caps, stipes and whole fruiting bodies of Yellow Knights mushrooms and the beneath top layer of soils from ten geographically distant locations in Poland. The Yellow Knights can be considered as an effective accumulator of total $\mathrm{Hg}$. The mean values of bioconcentration factor $(\mathrm{BCF})$ of $\mathrm{Hg}$ in caps of Yellow Knights for nine of the locations ranged from $22 \pm 9$ to $75 \pm 13$ (total range 9.0-90) and for stipes from $13 \pm 7$ to $52 \pm 9$ (total 4.4-93). The top layer $(0-10 \mathrm{~cm})$ of soils in these nine sites contained $\mathrm{Hg}$ with mean $( \pm \mathrm{SD})$ concentration ranging from $0.019 \pm 0.003$ to $0.046 \pm 0.007 \mathrm{ng} / \mathrm{g}$ dry weight. Mercury was less accumulated (BCF $4.9 \pm 2.7$ for a whole fruiting bodies) by Yellow Knights that emerged at the most contaminated site, where soil contained $0.059 \pm 0.028 \mathrm{ng} \mathrm{Hg} / \mathrm{g} \mathrm{dw}$. The potential of Yellow Knights communities to bioconcentrate $\mathrm{Hg}$ (determined as BCF) in fruiting bodies varied between the localities more than tenfold and decreased highly with increase of $\mathrm{Hg}$ content of the top soil.
\end{abstract}

Keywords Foods · Forest - Heavy metals · Organic food · Pollution · Suillus grevillei $\cdot$ Trace metals $\cdot$ Wild food

Mercury emissions and diffusion in the environment and contamination of food resources remain an actual problem of debate and concern worldwide. Wild grown mushrooms are highly vulnerable to $\mathrm{Hg}$ contamination (Falandysz et al. 2001a; Melgar et al. 2009). One of the reasons for elevated

D. Maćkiewicz · J. Falandysz ( $ه)$

Institute of Environmental Sciences and Public Health, University of Gdańsk, 18 Sobieskiego Str., 80-952 Gdańsk, Poland

e-mail: jfalandy@chem.univ.gda.pl
Hg content of forest mushrooms can be the degree of forest soil's pollution with this element (Suchara and Sucharová 2002). Wild grown mushrooms can be very effective accumulators of $\mathrm{Hg}$ and some of them highly bioconcentrated methyl mercury (Chudzyński et al. 2009, 2011; Drewnowska et al. 2012a, b; Falandysz 2012; Falandysz et al. 2012a, b; Grgić et al. 1992; Stijve and Roschnik 1974).

Yellow Knight Tricholoma equestre, mushroom, synonymous to "Man on Horseback" is specie popular during the fall and early winter and is widely distributed in Europe and North America (Læssøe et al. 1996). This mushroom is known also as Tricholoma flavovirens that is mycorrhizal with the conifer trees - especially of the Pinus family, and is found on sandy soils. In Poland the Yellow Knight is traditionally regarded as tasty mushroom, which is suitable for drying, pickling, stewing, souring and freezing. In a recipe on mushroom soups, "the Yellow Knights' soup", it is noted that the fresh specimens do not need to be blanched before soup cooking - that is the specimens, when "cleaned up, cut and well rinsed in running tap water, are poured directly into boiling bullion and boiled for $40 \mathrm{~min}$ ". A common practice is blanching of mushrooms (a shorttime boiling) by boiling them for $2,3,5$ or $10 \mathrm{~min}$ in boiling and slightly salty water - depending on the gourmet recipe. The Yellow Knight is officially registered as edible mushroom in Poland. There are some recent controversies on its edibility especially when consumed for several days in large amount. Because of this, in Germany, this mushroom is actually classified in the group of dangerous species.

This study documents the pollution of forest soil by $\mathrm{Hg}$ as well as the evaluating the $\mathrm{Hg}$ content, bioconcentration and distribution in T. equestre mushrooms collected from ten spatially distant sites in the Central Europe country of 
Poland. None of these sites surveyed was recognized as being under the influence of local $\mathrm{Hg}$ pollution.

\section{Materials and Methods}

The Yellow Knights, T. equestre (L.) P. Kumm., 1871, mushrooms and soil top layer $(0-10 \mathrm{~cm}$; ca. $100 \mathrm{~g})$ beneath to the fruiting bodies were collected from ten spatially distant areas across Poland in 1999-2007 (Table 1).

The fruiting bodies after careful cleanup from the plant material and particles of soil with a plastic knife were rinsed with distilled water and oven dried at $65^{\circ} \mathrm{C}$ to constant weight. Dried caps and stipes of fruiting bodies were milled in porcelain mortar and further kept in brand new sealed polyethylene bags in clean condition until chemical analysis. Soil substrate samples, after removal of the visible organisms, small stones, sticks and leaves were air dried under clean condition at room temperature for approximately 6 weeks and then sieved through a pore size of $2 \mathrm{~mm}$.

Total $\mathrm{Hg}$ content of materials was determined by coldvapour atomic absorption spectroscopy (CV-AAS). The samples matrix was pyrolised and the released mercury was first amalgamated and then desorbed from gold wool (Mercury analyzer type MA-2000, Nippon Instruments

Table 1 Total mercury concentrations in caps and stipes of T. equestre and beneath soil ( $\mu \mathrm{g} / \mathrm{g} \mathrm{dw})$, BCF and cap to stipe $\mathrm{Hg}$ content ration quotients $\left(\mathrm{Q}_{\mathrm{C} / \mathrm{S}}\right)$

\begin{tabular}{|c|c|c|c|c|c|c|}
\hline \multirow{2}{*}{$\begin{array}{l}\text { Land of Poland, site, year of } \\
\text { collection; number of specimens }\end{array}$} & \multicolumn{3}{|l|}{$\mathrm{Hg}$} & \multirow[t]{2}{*}{$\mathrm{Q}_{\mathrm{C} / \mathrm{S}}$} & \multicolumn{2}{|l|}{$\mathrm{BCF}$} \\
\hline & Caps & Stipes & Soil & & Cap & Stipe \\
\hline \multirow[t]{2}{*}{$\begin{array}{l}\text { Pomerania, Hel Peninsula, Hel, } \\
\text { 2004; } \mathrm{n}=15\end{array}$} & $\begin{array}{l}0.96 \pm 0.32 \\
(0.87)\end{array}$ & $\begin{array}{l}0.62 \pm 0.23 \\
(0.60)\end{array}$ & $\begin{array}{l}0.046 \pm 0.007 \\
(0.045)\end{array}$ & $\begin{array}{l}1.7 \pm 0.7 \\
(1.4)\end{array}$ & $\begin{array}{l}22 \pm 9 \\
(21)\end{array}$ & $\begin{array}{l}14 \pm 5 \\
(13)\end{array}$ \\
\hline & $0.45-1.5$ & $0.36-1.2$ & $0.038-0.059$ & $0.59-3.9$ & $9.0-37$ & $6.1-26$ \\
\hline \multirow[t]{2}{*}{$\begin{array}{l}\text { Pomerania, Kolbudy Forest } \\
\text { Inspectorate, Otomin, 2006; } \\
\mathrm{n}=13 \text { (29) }\end{array}$} & $\begin{array}{l}0.77 \pm 0.21 \\
(0.71)\end{array}$ & $\begin{array}{l}0.56 \pm 0.26 \\
(0.49)\end{array}$ & $\begin{array}{l}0.019 \pm 0.003 \\
(0.020)\end{array}$ & $\begin{array}{l}1.6 \pm 0.5 \\
(1.7)\end{array}$ & $\begin{array}{l}41 \pm 12 \\
(40)\end{array}$ & $\begin{array}{l}29 \pm 13 \\
(27)\end{array}$ \\
\hline & $0.49-1.3$ & $0.25-0.98$ & $0.012-0.022$ & $0.94-2.3$ & $23-60$ & $11-51$ \\
\hline \multirow[t]{2}{*}{$\begin{array}{l}\text { Pomerania, Rzecznica, 2003; } \\
\quad \mathrm{n}=10\end{array}$} & $\begin{array}{l}0.97 \pm 0.10 \\
(0.96)\end{array}$ & $\begin{array}{l}0.69 \pm 0.12 \\
(0.69)\end{array}$ & $\begin{array}{l}0.013 \pm 0.002 \\
(0.013)\end{array}$ & $\begin{array}{l}1.4 \pm 0.2 \\
(1.4)\end{array}$ & $\begin{array}{l}75 \pm 13 \\
(75)\end{array}$ & $\begin{array}{l}52 \pm 9 \\
(51)\end{array}$ \\
\hline & $0.83-1.1$ & $0.53-0.85$ & $0.010-0.016$ & $1.3-1.9$ & $59-90$ & $39-68$ \\
\hline \multirow[t]{2}{*}{$\begin{array}{l}\text { Kociewie Land, Tucholskie forest, } \\
\text { Łuby, 2001; } \mathrm{n}=14\end{array}$} & $\begin{array}{l}0.85 \pm 0.06 \\
(0.82)\end{array}$ & $\begin{array}{l}0.65 \pm 0.10 \\
(0.64)\end{array}$ & $\begin{array}{l}0.019 \pm 0.003 \\
(0.018)\end{array}$ & $\begin{array}{l}1.3 \pm 0.2 \\
(1.3)\end{array}$ & $\begin{array}{l}47 \pm 12 \\
(45)\end{array}$ & $\begin{array}{l}36 \pm 9 \\
(35)\end{array}$ \\
\hline & $0.62-1.3$ & $0.52-0.86$ & $0.013-0.025$ & $0.83-1.8$ & $33-72$ & $24-58$ \\
\hline \multirow[t]{2}{*}{$\begin{array}{l}\text { Kujawy Land, Ciechocinek, 2004; } \\
\mathrm{n}=15\end{array}$} & $\begin{array}{l}1.3 \pm 0.7 \\
(0.99)\end{array}$ & $\begin{array}{l}1.1 \pm 0.8 \\
(0.80)\end{array}$ & $\begin{array}{l}0.037 \pm 0.002 \\
(0.037)\end{array}$ & $\begin{array}{l}1.2 \pm 0.3 \\
(1.1)\end{array}$ & $\begin{array}{l}35 \pm 21 \\
(27)\end{array}$ & $\begin{array}{l}31 \pm 23 \\
(23)\end{array}$ \\
\hline & $0.57-2.8$ & $0.54-3.3$ & $0.035-0.039$ & $0.86-2.1$ & $15-81$ & $15-93$ \\
\hline \multirow{2}{*}{$\begin{array}{l}\text { Kujawsko-Pomorskie } \\
\text { Voivodeship, Brzoza, 1999; } \\
n=14\end{array}$} & $\begin{array}{l}0.71 \pm 0.11 \\
(0.72)\end{array}$ & $\begin{array}{l}0.68 \pm 0.14 \\
(0.71)\end{array}$ & $\begin{array}{l}0.028 \pm 0.006 \\
(0.026)\end{array}$ & $\begin{array}{l}1.1 \pm 0.1 \\
(1.1)\end{array}$ & $\begin{array}{l}26 \pm 6 \\
(25)\end{array}$ & $\begin{array}{l}25 \pm 7 \\
(25)\end{array}$ \\
\hline & $0.50-0.85$ & $0.43-0.91$ & $0.022-0.039$ & $0.83-1.2$ & $18-38$ & $15-35$ \\
\hline \multirow[t]{2}{*}{$\begin{array}{l}\text { Podlasie Land, Augustów, } \\
\text { 1998/1999; n = } 11\end{array}$} & $\begin{array}{l}0.25 \pm 0.07 \\
(0.24)\end{array}$ & $\begin{array}{l}0.17 \pm 0.04 \\
(0.16)\end{array}$ & $\begin{array}{l}0.036 \pm 0.009 \\
(0.037)\end{array}$ & $\begin{array}{l}1.5 \pm 0.2 \\
(1.5)\end{array}$ & $\begin{array}{l}24 \pm 8 \\
(20)\end{array}$ & $\begin{array}{l}20 \pm 7 \\
(17)\end{array}$ \\
\hline & $0.17-0.36$ & $0.11-0.23$ & $0.021-0.047$ & $1.2-1.8$ & $14-40$ & $14-31$ \\
\hline \multirow[t]{2}{*}{$\begin{array}{l}\text { Podlasie Land, Augustów, 2006; } \\
\mathrm{n}=15\end{array}$} & $\begin{array}{l}0.81 \pm 0.10 \\
(0.80)\end{array}$ & $\begin{array}{l}0.63 \pm 0.06 \\
(0.63)\end{array}$ & $\begin{array}{l}0.035 \pm 0.001 \\
(0.037)\end{array}$ & $\begin{array}{l}1.3 \pm 1.3 \\
(1.3)\end{array}$ & $\begin{array}{l}25 \pm 8 \\
(20)\end{array}$ & $\begin{array}{l}19 \pm 6 \\
(17)\end{array}$ \\
\hline & $0.68-0.94$ & $0.53-0.74$ & $0.021-0.047$ & $1.0-1.5$ & $15-40$ & $14-31$ \\
\hline $\begin{array}{l}\text { Mazowsze Land, Commune of } \\
\text { Kościelna Wieczfnia, 2006; } \\
\mathrm{n}=13\end{array}$ & $\begin{array}{l}0.23 \pm 0.06^{\mathrm{a}} \\
(0.21) \\
0.16-0.32\end{array}$ & & $\begin{array}{l}0.059 \pm 0.028 \\
(0.060) \\
0.031-0.13\end{array}$ & NA & $\begin{array}{l}4.9 \pm 2.7 \\
(4.0) \\
(1.2-9.6)\end{array}$ & \\
\hline \multirow[t]{2}{*}{$\begin{array}{l}\text { Lubelskie Land, Chodelska Dale, } \\
\text { Poniatowa, 1999-2001; } n=13\end{array}$} & $\begin{array}{l}0.84 \pm 0.42 \\
(0.56)\end{array}$ & $\begin{array}{l}0.49 \pm 0.30 \\
(0.45)\end{array}$ & $\begin{array}{l}0.039 \pm 0.007 \\
(0.036)\end{array}$ & $\begin{array}{l}1.9 \pm 1.8 \\
(1.8)\end{array}$ & $\begin{array}{l}22 \pm 12 \\
(18)\end{array}$ & $\begin{array}{l}13 \pm 7 \\
(13)\end{array}$ \\
\hline & $0.46-1.8$ & $0.15-1.1$ & $0.030-0.050$ & $1.0-3.6$ & $9.3-56$ & $4.4-25$ \\
\hline
\end{tabular}

NA not applicable

${ }^{\text {a }}$ Whole fruiting bodies 
Corporation, Takatsuki, Japan). Analytical control and assurance quality (AC/AQ) were achieved by the analysis of several reference standard materials (Jarzyńska and Falandysz 2011). One of these materials was the CS-M-1 certified reference material (dried fruiting bodies of mushroom Cow Bolete (Suillus bovinus) produced by the Institute of Nuclear Chemistry and Technology in Warsaw, Poland. This material is routinely used in the analysis performance check-up and its' declared total $\mathrm{Hg}$ content is $0.174 \pm 0.018 \mu \mathrm{g} / \mathrm{g} \mathrm{dw}$. In this study, $\mathrm{Hg}$ content of the CS-M-1 certified reference material was $0.176 \pm 0.004 \mu \mathrm{g} / \mathrm{g} \mathrm{dw}(\mathrm{n}=3)$. With every set of 10 mushroom or soil samples examined one blank sample was run and no interference was noted. The analytical equipment under the condition used enabled the determination of $\mathrm{Hg}$ at linear range spanning from 0.002 to $1,000 \mathrm{ng}$ in a sample of up to $0.5 \mathrm{~g}$ mass. Discrepancies between the certified values and concentrations quantified were well below $10 \%$. Duplicates and blanks followed with every set of ten samples examined. For blank samples, no major interferences were found for the elements quantified. Limit of detection for $\mathrm{Hg}$ was $0.005 \mu \mathrm{g} \mathrm{Hg} / \mathrm{g}$ dw. Coefficients of variation for these measurements on routine runs were well below $10 \%$.

All data produced were statistically treated using the computer software Statistica version 8.0.

\section{Results and Discussion}

Data on $\mathrm{Hg}$ content of top layer of forest soils and fruiting bodies of T. equestre as well as on the $\mathrm{Hg}$ distribution between caps and stipes and the $\mathrm{Hg}$ bioconcentration factor (BCF) values by species are presented in Table 1.

The unit less BCF value is used as a measure of accumulation potential of elements by mushroom. The BCF is a quotient of chemical element content in fruiting body against its content in soil substratum. The BCF values of $\mathrm{Hg}$ in caps and stipes of $T$. equestre were rather high for most sites and did indicate a strong potential of this mushroom to sequestrate $\mathrm{Hg}$. BCF up to 90 was noted in a single cap, while median values of BCF varied for most of the sites between 18 and 75 ; the mean values ranged from $22 \pm 9$ to $75 \pm 13$ (Table 1). In the Commune Kościelna Wieczfnia of the Mława County, the mean value of BCF was $4.9 \pm 2.7$ (median was 4), and this is distinctly low compared to other areas in this study. Mercury content of top layer of forest soil in the Commune Kościelna Wieczfnia was higher compared to other sites examined, i.e. $0.059 \pm 0.028 \mu \mathrm{g} / \mathrm{g} \mathrm{dw}$, while median for nine other sites varied between 0.013 and $0.045 \mu \mathrm{g} / \mathrm{g} \mathrm{dw}$, and the means ranged from $0.019 \pm 0.003$ to $0.046 \pm 0.007 \mathrm{ng} / \mathrm{g}$ (Table 1). Nevertheless, these data on $\mathrm{Hg}$ in forest soils do not show any on pollution problem and could be considered as "baseline" levels.
Mercury content was higher in caps compared to stipes of $T$. equestre. The median values of the quotient of $\mathrm{Hg}$ content in cap to $\mathrm{Hg}$ content in stipe $\left(\mathrm{Q}_{\mathrm{C} / \mathrm{S}}\right)$ varied from 1.1 to 1.8 (Table 1). In this study, for seven of the sites examined $\mathrm{Hg}$ content of caps ranged from $0.71 \pm 0.11$ to $1.3 \pm 0.7 \mu \mathrm{g} / \mathrm{g} \mathrm{dw}$ (median values were from 0.72 to $0.99 \mu \mathrm{g} / \mathrm{g} \mathrm{dw}$ ) and for two other sites in one case in caps was $0.25 \pm 0.07 \mu \mathrm{g} / \mathrm{g} \mathrm{dw}$ (median $0.24 \mu \mathrm{g} / \mathrm{g} \mathrm{dw}$ ) and in another (in a whole fruiting body) was $0.23 \pm 0.06 \mu \mathrm{g} /$ $\mathrm{g} \mathrm{dw}$ (median $0.21 \mu \mathrm{g} / \mathrm{g} \mathrm{dw}$ ) (Table 1). In some earlier studies of $T$. equestre, the specimens examined contained $\mathrm{Hg}$ in caps of $0.94 \pm 0.74 \mu \mathrm{g} / \mathrm{g} \mathrm{dw}(\mathrm{n}=3 ; 1994)$ and $1.7 \pm 0.9 \mu \mathrm{g} / \mathrm{g} \mathrm{dw}(\mathrm{n}=14 ; 1996-1997)$ (Falandysz et al. 2001b, 2003). Based on data on total Hg in T. equestre in this and earlier studies it can be concluded that a site to site variation of $\mathrm{Hg}$ content over years can be up to ten-fold, while the upper mean and median content in caps did not exceed $2.0 \mu \mathrm{g} / \mathrm{g} \mathrm{dw}$.

Mercury accumulated in fruiting bodies of mushrooms might pose health risk for consumers. In countries where T. equestre grows, it could be eaten by some individuals in relatively large amount within a week. Intoxication was noted after eating $1,200 \mathrm{~g}$ (fresh weight) fruiting bodies of T. equestre in 5 days by a boy of age 5 years (Chodorowski et al. 2003). Locally, in autumn in pine forests T. equestre can be very abundant. This mushroom, after blanching (boiled, pickled) or without blanching (salted) are usually eaten at a rate of around 300-400 g daily - during 3-4 days in a week.

The $\mathrm{Hg}$ reference dose (RfD) of $0.0003 \mathrm{mg} / \mathrm{kg}$ body weight/day and provisional tolerable weekly intake value of $0.004 \mathrm{mg} / \mathrm{kg}$ bw for person of $70 \mathrm{~kg}$ bw can be applied to assess health risk to consumers due to $\mathrm{Hg}$ taken from foods (JECFA 2010; US EPA 1987).

A meal made of 300 or $400 \mathrm{~g}$ fresh caps or whole fruiting bodies of $T$. equestre containing $0.24-0.25 \mu \mathrm{g} \mathrm{Hg} / \mathrm{g} \mathrm{dw}$ on the average (two sites, Table 1) could provide from $0.0072-0.0075$ to $0.096-0.010 \mathrm{mg} \mathrm{Hg}$ (assuming $90 \%$ of moisture in fresh mushrooms). For eight other sites, where the mean value of $\mathrm{Hg}$ in caps were higher, i.e. between 0.71 and $1.3 \mu \mathrm{g} \mathrm{Hg} / \mathrm{g} \mathrm{dw}$, a mushroom dish of similar volume could provide from $0.021-0.039$ to $0.028-0.052 \mathrm{mg} \mathrm{Hg}$, on the average. These values, calculated for a person of $60-\mathrm{kg}$ body weight gave a range of 0.00035 and $0.00087 \mathrm{mg} /$ $\mathrm{kg}$ bw, which are doses exceeding the RfD of $\mathrm{Hg}$ and show elevated risks from the consumption of this mushroom. On the other site $\mathrm{Hg}$ intake from such meals eaten seven times in a week will provide from 0.149 to 0.199 and from 0.27 to $0.36 \mathrm{mg} \mathrm{Hg}$, and these are intakes equivalent to 2.1-2.8 and $3.9-5.2 \mu \mathrm{g} \mathrm{Hg} / \mathrm{kg}$ bw respectively. For some of the sites examined (Table 1) Hg intake solely from caps of T. equestre is close to or above the PTWI of $\mathrm{Hg}$.

As reported in Table 1, the Yellow Knights, even if they emerged at sites unpolluted with $\mathrm{Hg}$, are mushroom species 
that are usually contaminated with elevated concentrations of this element, which is a feature common to certain other edible wild mushrooms (Falandysz et al. 2002, 2004, 2007a, b).

Data on methylmercury $\left(\mathrm{CH}_{3} \mathrm{Hg}^{+}\right)$content and proportion to total $\mathrm{Hg}$ in $T$. equestre are not available. Selenium in foods is considered as element that to some degree is also able to reduce or eliminate toxicity from $\mathrm{Hg}$ and $\mathrm{CH}_{3} \mathrm{Hg}^{+}$. Mercury can form species hardly soluble in water such as $\mathrm{HgSe}$ and $\mathrm{HgS}$ but nothing is known on such $\mathrm{Hg}$ compounds in mushrooms. Knowledge of $\mathrm{Se}$ and $\mathrm{Hg}$ interactions in flesh of mushrooms is also non-existing. Selenium content of T. equestre is known only from a single study and the reported Se concentration of $2.8 \pm 0.3(2.5-3.2 ; \mathrm{n}=4) \mu \mathrm{g} / \mathrm{g}$ dw seems overestimated (cited after Falandysz 2008).

Acknowledgments Technical assistance by Anna Chylicka, Karolina Lubiejewska, Maja Mackiewicz, Aleksandra Maternik, Dominika Milewska and Alina Pękacka is acknowledged. This study was supported by the Ministry of Science and Higher Education under project DS-8130-4-0092-1.

Open Access This article is distributed under the terms of the Creative Commons Attribution License which permits any use, distribution, and reproduction in any medium, provided the original author(s) and the source are credited.

\section{References}

Chodorowski Z, Anand J, Grass M (2003) Acute poisoning with Tricholoma equestre of five-year old child. Przegląd Lekarski 60:309-310

Chudzyński K, Bielawski L, Falandysz J (2009) Mercury bioconcentration potential of Larch Bolete, Suillus grevillei, mushroom. Bull Environ Contam Toxicol 83:275-279

Chudzyński K, Jarzyńska G, Stefańska A, Falandysz J (2011) Mercury content and bio-concentration potential of Slippery Jack, Suillus luteus, mushroom. Food Chem 125:986-990

Drewnowska M, Jarzyńska G, Kojta AK, Falandysz J (2012a) Mercury in European Blusher, Amanita rubescens, mushroom and soil. Bioconcentration potential and intake assessment. J Environ Sci Health Part B 47:466-474

Drewnowska M, Jarzyńska G, Sąpór A, Nnorom IC, Sajwan KS, Falandysz J (2012b) Mercury in Russula mushrooms: bioconcentration by Yellow-ocher Brittle Gills Russula ochroleuca. J Environ Sci Health Part A 47:1577-1591

Falandysz J (2008) Selenium in edible mushrooms. J Environ Sci Health Part C 26:256-299

Falandysz J (2012) Comments on "Determination of mercury, cadmium, lead, zinc, selenium and iron by ICP-OES in mushroom samples from around thermal power plant in Muğla, Turkey". Bull Environ Contam Toxicol 88:651-653. doi:10.1007/s00128-0110357-1
Falandysz J, Gucia M, Frankowska A, Kawano M, Skwarzec B (2001a) Total mercury in wild mushrooms and underlying soil substrate from the city of Umeå and its surroundings, Sweden. Bull Environ Contam Toxicol 67:763-770

Falandysz J, Szymczyk K, Ichihashi H, Bielawski L, Gucia M, Frankowska A, Yamasaki S (2001b) ICP/MS and ICP/AES elemental analysis (38 elements) of edible wild mushrooms growing in Poland. Food Addit Contam 18:503-513

Falandysz J, Gucia M, Skwarzec B, Frankowska A, Klawikowska K (2002) Total mercury in mushrooms and underlying soil from the Borecka forest, northeastern Poland. Arch Environ Contam Toxicol 42:145-154

Falandysz J, Brzostowski A, Kawano M, Kannan K, Puzyn T, Lipka $\mathrm{K}$ (2003) Concentrations of mercury in wild growing higher fungi and underlying substrate near Lake Wdzydze, Poland. Water Air Soil Poll 148:127-137

Falandysz J, Jędrusiak A, Lipka K, Kannan K, Kawano M, Gucia M, Brzostowski A, Dadej M (2004) Mercury in wild mushrooms and underlying soil substrate from Koszalin North-central Poland. Chemosphere 54:61-466

Falandysz J, Frankowska A, Mazur A (2007a) Mercury and its bioconcentration factors in King Bolete (Boletus edulis) Bull. Fr. J Environ Sci Health Part A 42:2089-2095

Falandysz J, Gucia M, Mazur A (2007b) Content and bioconcentration factors of mercury by Parasol Mushroom Macrolepiota procera. J Environ Sci Health Pt B 42:735-740

Falandysz J, Widzicka E, Kojta AK, Jarzyńska G, Drewnowska M, Danisiewicz-Czupryńska D, Dryżałowska A, Lenz E, Nnorom IC (2012a) Mercury in common Chanterelles mushrooms: Cantharellus spp. update. Food Chem 133:842-850

Falandysz J, Kojta AK, Jarzyńska G, Drewnowska A, Dryżałowska A, Wydmańska D, Kowalewska I, Wacko A, Szlosowska M, Kannan K, Szefer P (2012b) Mercury in bay bolete Xerocomus badius: bioconcentration by fungus and assessment of element intake by humans eating fruiting bodies. Food Addit Contam A 29:951-963

Grgić J, Mandić M, Grgić Z, Manić Z (1992) Diva i arsen u samoniklim jestivim i nejestivim gljivama. Farm Glas 48:183-189

Jarzyńska G, Falandysz J (2011) The determination of mercury in mushrooms by CV-AAS and ICP-AES techniques. J Environ Sci Health Part A 46:569-573

JECFA (2010) Joint FAO/WHO expert committee on food additives. Seventy-second meeting. Rome, 16-25 February 2010. Summary and conclusions. JECFA/72/SC. Food and Agriculture Organization of the United Nations World Health Organization. Issued 16th March 2010

Læssøe T, Del Conte A, Lincoff G (1996) The mushroom book, 1st American ed. A DK Publishing Book, London, UK

Melgar MJ, Alonso J, Garcia MÁ (2009) Mercury in edible mushrooms and soil. Bioconcentration factors and toxicological risk. Sci Total Environ 407:5328-5334

Stijve T, Roschnik R (1974) Mercury and methyl mercury content of different species of fungi. Trav Chim Aliment Hyg 65:209-220

Suchara I, Sucharová J (2002) Distribution of sulphur and heavy metals in forest floor humus of the Czech Republic. Water Air Soil Pollut 136:289-316

US EPA (1987) United States Environmental Protection Agency peer review workshop on mercury issues. summary report. Environmental criteria and Assessment Office. Cincinnati, U.S. EPA, OH, 26-27 Oct 1987 